Stefan Norrthons avhandling visar att han väl behärskar den multimodala interaktionsanalysens teori och metoder, och är kapabel att leverera klart originella resultat av relevans såväl för fältet som för den vidare teaterforskningen. Särskilt imponerande är den datainsamling som ligger till grund för arbetet, inte endast att Norrthon fått tillgång till fältet utan också hur repetitionsarbetet videodokumenterats och därefter transkriberats med stor noggrannhet. Vissa smärre skavanker i transkriptioner och översättningar till engelska bör inte skymma den överlag goda helheten vad gäller datahanteringen. Ibland anar man i analysen en lust att skriva fram alltför tydliga resultat, det blir lite för svart-vitt. Det antagligen tydligaste exemplet på detta är när Norrthon kommer fram till att teaterarbete snarare är ett samarbete mellan skådespelare och regissör än (enkelriktad) instruktion från regissören. Redan många av denna avhandlings egna utdrag visar dock ofta regissören i färd med att leverera just instruktioner till skådespelarna - det måste alltså vara både och. Ytterligare invändningar kan göras mot att den för interaktionsanalysen centrala sekvensanalysen särskilt i kappan får stå tillbaka väl mycket till förmån för den jämförande longitudinella analysen, och att man på något ställe kan skönja en lust att generalisera bortom vad som är rimligt med hänsyn till tillgängliga data.

Stefan Norrthon skriver bra, och har då och då också modet att uttrycka sig friskt okonventionellt. Ett råd till framtida läsare är att börja med artiklarna och sedan läsa kappan. Börjar man med kappan får man vänta väl länge på det första transkriberade datautdraget (vilket återfinns först på s. 46). Dessutom hjälper analyserna i artiklarna läsaren att förstå många potentiella oklarheter i kappan.

Kappan är relativt kort, och möjligtvis upprepas väl mycket innehåll från artiklarna i stället för att utnyttja utrymmet för att ge läsaren något annat och mera. Å andra sidan är det bra att kappan erbjuder en uppsättning begrepp som håller ihop avhandlingen på ett tydligt sätt. Sammanfattningsvis måste sägas att Stefan Norrthon genom sin avhandling givit oss mycket ny kunskap om teaterrepetitionen som institutionell aktivitet och dess konstituerande praktiker.

\title{
Mathias Broth
}

Sandberg, Malin, 2020: Från beslut till broschyr. Intertextualitet, äldre och kultur i texter inom en statlig satsning. (Göteborsstudier i nordisk språkvetenskap 40.) Diss. 209 s. Göteborg: Göteborgs universitet. ISSN 1652-3105, ISBN 978-91-87850-77-6.

Malin Sandberg undersöker i sin avhandling texter inom en statlig kultursatsning för äldre. Närmare bestämt handlar det om textkedjor från regeringens beslut via Kulturrådets utlysning, till ansökningar, rapporter om kulturprojekt och slutligen Kulturrådets broschyrer om projekten - kort sagt om vägen från beslut till broschyr.

Avhandlingen består av nio kapitel. I det första kapitlet presenteras och motiveras undersökningen. Sandbergs syfte är att »dels kartlägga hur intertextuella relationer tar sig uttryck i texter från en statlig satsning på kultur för äldre, dels belysa hur diskurser om 
äldre och kultur kommer till uttryck i satsningens texter» (s. 2). De fyra empirikapitlen handlar om intertextualitet i institutionella kontexter, representationer av äldre, konstruktioner av satsningens meningsfullhet och kultur för äldre i bild.

Kapitel 2 presenterar modern svensk kulturpolitik som haft och har måluppfyllelse, utvärderingsbarhet och mätbarhet som utgångspunkter. Kriterier som t.ex. hög konstnärlig kvalitet, förnyelse eller originalitet är dock svåra att mäta, och det är också problematiskt att kulturpolitik och kulturpolitiska satsningar både kopplas till andra politikområden som invandrare, ungdomar eller äldre och är beroende av projektsatsningar. Sandbergs material utgörs av ett sådant projekt. Statens kulturråd fick 20112013 i uppdrag av regeringen att fördela 80 miljoner för att »främja kultur för äldre inom sjukvård och omsorgsverksamhet». Sandgren ger satsningen det tydliga namnet Kultur för äldre. Projektet skulle ge bidrag till projekt av vård- och omsorgsaktörer och knytas till fältet kultur och hälsa för äldre. Sandgren visar också på att begreppet äldre är vagt och homogeniserande så att de medelålders självklara heterogenitet (klass, utbildning, etnicitet, profession etc.) suddas ut när de gått från att vara medelålders till att bli äldre. Projektet Kultur för medelålders vore alltså ingen möjlig satsning för Statens kulturråd!

Kapitel 3 har titeln Teoretiska och metodologiska utgångspunkter. Titeln känns igen för den som läst avhandlingar inom det diskursanalytiska fältet eftersom teori och metod är sammanflätade inom diskursanalys. Sandberg diskuterar begreppen diskurs, interdiskursivitet, intertextualitet, rekontextualisering, textkedjor och transformationer. De intertextuella analyserna i kapitel 5 utgår från begreppen intertextualitet, textkedjor och rekontextualisering. Det intertextuella temat finns genom hela avhandlingen, men för kapitel 6 och 7 är också begreppen transformationer och sociala praktiker viktiga eftersom Sandberg här analyserar representationer av de äldre respektive konstruktioner av kultur. I de visuella analyserna i kapitel 8 finns även ett sociosemiotiskt perspektiv.

Avhandlingens material beskrivs utförligt i kapitel 4. Sandberg har analyserat beslutsfasen (regeringsbesluten), tilldelningsfasen (Statens kulturråds utlysningstext och fördelningsbeslut samt ansökningstexterna), projekttiden (projektinformation och projektrapporter) samt utvärdering och dokumentation (utvärderingsrapport av extern utvärderare och informerande broschyrer från Statens kulturråd). Detta resulterar i textkedjor med inbäddade texter utifrån olika innehåll och perspektiv forskning, kulturpolitik, äldrepolitik, annan politik, enskilda personer eller yrkesgrupper.

Inom satsningen på Kultur för äldre beviljades totalt 50 projekt, och Sandberg har valt ut tre av dessa utifrån följande kriterier:

För det första är de alla förhållandevis väl avgränsade från andra verksamheter och aktörer som studieförbund och liknande, och helt ägda av landsting/regioner och kommuner. Det gör att texterna är mer lättillgängliga för mig som forskare och att projektens verksamheter förhållandevis lätt går att beskriva och avgränsa. För det andra har alla tre projekten i någon mån involverat att äldre antingen varit (med)skapande eller publik i kulturverksamhet, till skillnad från de projekt där äldre varit forskningsobjekt eller bara sekundärt involverade. För det tredje representerar projekten delvis olika former av konstfor- 
mer, vilket ger materialet en viss bredd. För det fjärde har de valda projekten också en viss geografisk spridning. Slutligen har samtliga tre projekt dokumenterat sin verksamhet i form av en självständig slutrapport, vilket inte alla lokala projekt har gjort. (s. 44)

Kapitel 5 är det första empiriska kapitlet. Sandberg bygger vidare på den intertextuella beskrivningen från materialkapitlet genom intertextuella analyser inom materialet. När de explicita textrelationerna utgörs av hänvisningar som är precisa och systematiska benämner Sandberg det stark textrelation medan svag textrelation betecknar svaga eller sporadiska hänvisningar. Rekontextualiserade formuleringar är en annan typ av intertextualitet. Sandberg ser både typerna av intertextualitet som former av manifest intertextualitet. Den förra ger hon beteckningen explicit manifest intertextualitet och den andra dold manifest intertextualitet. Ett resultat är att explicita textrelationer och rekontextualiserade formuleringar är vanliga mellan de centrala textaktörerna regeringen och Kulturrådet. Formuleringen ger positiva hälsoeffekter rekontextualiseras i många av textslagen - regeringsbeslut, utlysning, fördelningsbeslut, utvärdering och informerande broschyrer - vilket förklaras av att satsningen vill bekräfta sambandet mellan kultur och hälsa för äldre.

Det sjätte kapitlet analyserar representationer av deltagare genom en kombination av Membership Categorization Analysis och andra diskursanalytiska analyser av sociala aktörer. För detta kapitel och de följande empirikapitlen används av förklarliga skäl ett delmaterial. Sandbergs perspektiv är socialkonstruktivistiskt och hon intresserar sig för språkbrukarnas beteckningar och kategorisering. Det tydligaste och inte oväntade resultatet är att äldre är den viktigaste kategoriseringen - med eller utan bestämningar, med eller utan kopplingar till vårdbehov eller boendeform. Beteckningen kan också tolkas som en kortform av satsningens målgrupp »äldre inom sjukvård och omsorgsverksamhet». Ett annat resultat är att äldre sällan kopplas till kulturskapande i materialet trots att projekten vill främja äldre som kulturutövare. I det projekt där de äldre omnämns som kulturskapare är dock tonen skämtsam, så att effekten snarast blir att cementera det oförenliga mellan äldre och kulturskapande, åtminstone när det gäller äldre på särskilda boenden. Den äldrediskurs som träder fram konstruerar äldre som svaga, beroende, sjuka och som mottagare av kultur.

Kapitel 7 handlar om hur kultur för äldre konstrueras som meningsfullt med van Leeuwens $(2000,2008)$ modell för syfteskonstruktioner som utgångspunkt. Huvudtyperna för syfteskonstruktion är mål, medel eller effekt. Det som binder samman materialet är tron på och syftet att kultur gör gott och att kultur kan användas både för att förbättra livet för de äldre och för att uppnå kulturpolitiska mål. De flesta syfteskonstruktionerna gäller de äldre, både för att höja deras livskvalitet och för att förbättra deras hälsa. Det är dock uppenbart att kultursatsningen inte bara är till för de äldres skull eftersom den beskrivs ge effekter för personalen, den regionala utvecklingen och kulturarbetarna. De 80 miljonerna i kulturpolitisk satsning för äldre vill Kulturrådet kunna utvärdera och mäta vilket är lättare sagt än gjort. Sandberg visar att det kan göras genom indirekta formuleringar:

För att uttrycka det krasst skriver man kanske ogärna att man satsar på kultur för att äldre ska äta behöva mindre medicinering, medan man däremot kan tänka sig att uttrycka det som att kultur kan minska tablettanvändning. Det sistnämnda sät- 
tet förpliktigar inte, men konstruerar trots det den meningsfullhet som behöver uttryckas. (s. 141)

Slutligen analyseras de 58 bilder som förekommer i materialet utifrån Kress \& van Leeuwens (2006) visuella grammatik och svenska tillämpningar som Björkvall 2009. Modellen utgår från tre funktioner - den textuella, den interpersonella och den ideationella funktionen med tonvikt på den sistnämnda eftersom Sandberg ser den som lättast att knyta till analyserna av deltagares representation och konstruktioner av meningsfullhet i de två föregående kapitlen. I bilderna av de äldre som deltagare finns två tydliga attribut som knyts till hög ålder: åldrad hud och grått hår. Det är också vanligt med attribut som har att göra med funktionsnedsättningar som rullatorer och rullstolar. Meningsfullhet konstrueras i bilderna genom att äldre deltar i kulturaktiviteter men också genom att bilderna skildrar situationer av gemenskap och närhet.

Avhandlingens främsta bidrag är de välutvecklade analyserna av textkedjor, textrelationer och rekontextualiseringar. Sandberg redovisar de olika typerna av textkedjor tydligt och visar hur de byggs upp av både starkare och svagare textrelationer. Mindre lyckade är däremot beteckningarna explicit manifest intertextualitet respektive dold manifest intertextualitet - i det förra fallet resulterar det i en tautologi och i det senare fallet i en oxymoron. Enklare och tydligare termer hade varit explicit textsamspel respektive implicit textsamspel (Rahm \& Sandell 2016). Men detta är en randanmärkning eftersom analyserna och resonemangen är mycket väl genomförda. Sandberg visar genom rekontexualiseringsanalyserna av begreppet äldre att Kulturrådets i sin broschyr framställer stereotypisering av äldre som ett separat samhällsproblem medan utvärderingen visar att problemet finns bland projektverksamhetens anställda. Det är ett tydligt sätt att visa hur perspektiv kan förskjutas mellan kontexter!

Analyserna av deltagarrepresentation är väl genomförda med bl.a. det intressanta resultatet att beteckningarna äldre, senior, pensionär används i relief mot beteckningar för yngre men att de kronologiska åldrarna däremellan lyser med sin frånvaro. Texternas de syftar på de äldre, medan vi:et står för icke-äldre $i$ allmänhet eller mer specifikt de icke-äldre som står bakom texten såsom textansvariga på kommun eller landsting. Med tanke på Sandbergs kritik mot det homogeniserande äldrebegreppet är det förvånande att hon inte visar på den skillnad som görs av SCB mellan yngre äldre (65-79) och äldre äldre $(80+)$. Denna vidareindelning är viktig och används inom äldreforskning i syfte att urskilja äldres behov av vård och omsorg beroende på ålder. Statistiskt sett ökar behovet med stigande ålder, och det finns få yngre äldre på särskilda boenden. Kommuner och landsting är väl medvetna om åldersgruppernas skilda vårdbehov och ser definitivt inte äldre som en homogen grupp. En diskussion om denna indelning hade varit på sin plats i anslutning till Sandbergs resonemang om indelningar och representationer av äldre:

Att den generiska beteckningen äldre ändå används här, bidrar till en generalisering av äldre i allmänhet, som kan ses som problematisk. Den bidrar till att reproducera diskurser om äldre som beroende, och kanske sjuka och boende på särskilda boenden, allt i linje med grundfiguren av äldre. (s.118)

Jag både håller med och håller inte med om att detta kan tolkas som en generalisering av äldre i allmänhet. I Kulturrådets utlysning talas det om landsting, kommuner och pri- 
vata vård- och omsorgsgivare som tänkta mottagare av projektmedlen. Det betyder att äldre bara är en kortform av »äldre inom sjukvård och omsorgsverksamhet». En annan möjlig slutsats är att satsningen är till för de knappt $5 \%$ av de äldre som bor på särskilda boenden.

Sandberg väjer inte för det svåra att utveckla van Leeuwens metodskiss för syfteskonstruktioner, en skiss som varken erbjuder olika analysnivåer eller grader av abstraktion. Denna utveckling och operationalisering lyckas hon väl med. Detta är en självklar styrka, men tanken inställer sig om det inte hade varit bättre för Sandberg att utgå från en annan och mer välutvecklad modell. Vi språkvetare som använt oss av van Leeuwens modeller behöver alla lite till mans fundera på om och hur vi ska bygga på van Leeuwens olika ramverk i de fall där allt inte är välutvecklat. Sandbergs slutsats är kritisk och välformulerad som att det kan ses som »en aning anmärkningsvärt att det är vanligare att man konstruerar syften som t.ex. effekter för vårdpersonal, kulturarbetare och regional utveckling osv., än att man konstruerar syften som rör kultur och konstnärliga värden» (s. 139).

Sandberg förhåller sig inte okritisk till den kategoriska visuella grammatiken i Kress \& van Leeuwens modell och undviker på så sätt generaliseringar och förenklingar. I de visuella analyserna ser Sandberg bilderna som »varken tydligt förskönande eller präglade av någon föreställning om förfall» (s. 164). Hon jämför med reklamens bilder där målgruppen ofta förskönas. Slutsatsen kan dock även bli den omvända, att kultursatsningen motiveras med bilder av lyckade kulturaktiviteter där den äldre på det särskilda boendet är glad och aktiv. Detta är snarast en skönmålning eftersom det kroppsliga och kognitiva förfallet hos de äldre inom sjukvård och omsorgsverksamhet är en stor utmaning både för de äldre och personalen. Med tanke på att den kulturpolitiska satsningen ska motiveras av alla parter kan bilderna lika väl tolkas som ett medel att befästa föreställningen om sambandet mellan kultur och hälsa för äldre.

Analyserna av representationer av deltagare, syfteskonstruktioner och de visuella analyserna återkopplas till de intertextuella analyserna. Sandberg drar övergripande slutsatser som att textsamspel (eller manifest intertextualitet) bör studeras både genom textkedjor och rekontextualiseringar. Hon har förmågan att vara välgrundat kritisk mot spinnord som social samvaro, meningsfullhet och skapande som används på ett minst sagt vagt sätt. Samtidigt har hon förståelse för att det kan finnas bakomliggande förklaringar till detta språkbruk som vi inte har kännedom om. Sandbergs avhandling kommer att vara till stor nytta för framtida analyser av textkedjor, diskurser och rekontextualiseringar inom både myndigheter och andra organisationer. Den är också ett viktigt bidrag till att förstå hur olika deltagare kategoriseras, skildras och representeras samt hur syften uttrycks, konstrueras och rekonstrueras.

\section{Litteratur}

Björkvall, Anders, 2009: Den visuella texten. Multimodal analys i praktiken. (Ord och stil 40.) Stockholm: Hallgren \& Fallgren.

Kress, Günther \& van Leeuwen, Theo, 2006: Reading Images. The Grammar of Visual Design. 2 uppl. London/New York: Routledge. 
Rahm, Henrik \& Sandell, Niklas, 2016: Att legitimera priset på förvärvat företag. Intertextuella förhållanden i goodwillformuleringar. I: Sakprosa 8(3). S. 1-33.

van Leeuwen, Theo, 2007: Legitimation in discourse and communication. I: Discourse \& Communication 1(1). S. 91-112.

van Leeuwen, Theo, 2008: Discourse and Practice. New Tools for Critical Discourse Analysis. Oxford: Oxford University Press.

Henrik Rahm

Svahn, Elin \& Meister, Lova (red.), 2020: Översättningsvetenskap i praktiken. Om översättningar, översättare och översättande. 207 s. Stockholm: Morfem. ISBN 978-91-88419-187.

Som någon som har haft nordistiken och språkvetenskapen som språngbräda in i det ursprungligen tvärvetenskapliga fältet översättningsvetenskap, har jag möjligen ett något överdrivet intresse för översättningsvetenskapens relation till andra forskningsområden. Kanske är det därför jag delvis ser Översättningsvetenskap i praktiken. Om översättningar, översättare och översättande som ännu ett steg i översättningsvetenskapens självständighetsprocess. Jag återkommer till detta.

Tvärvetenskapliga ämnen kan ofta inledningsvis bli ett lapptäcke, eller framstå som småsyskon i kläder ärvda från olika håll - teorier från en disciplin, analysmetoder från en annan. Som forskare eller student inom området får man då lära sig områdets teorier och metoder genom att läsa litteratur ursprungligen skriven för andra ämnesområden. Översättningsvetenskapen har lämnat den fasen, och det finns sedan länge kursböcker för olika nivåer skrivna för just översättningsvetenskap, men fortfarande har det saknats svenskspråkig litteratur inom vissa delar av området. Det är en sådan lucka den här boken, enligt redaktörerna, är avsedd att fylla.

Boken inleds med en »introduktion till metodologi i översättningsvetenskap». Därefter följer fem separata forskningsartiklar, från olika inriktningar inom översättningsvetenskapen. Boken avslutas med ett antal instuderingsfrågor som är kopplade till introduktionskapitlet, en lista över lästips om metod och metodologi inom ämnet och slutligen en bibliografi över svenska översättningsrelaterade doktorsavhandlingar från åren 1986-2018.

Den inledande metodologidelen, skriven av Lova Meister, presenterar ett ramverk bestående av tre domäner som berör olika delar av metodologin. Metodologi definieras här brett och avser att spänna över såväl en studies teoretiska underbyggnad som dess praktiska genomförande. Under rubriken »Filosofiska och teoretiska ansatser» berörs ontologi och epistemologi, etik och olika syn på teori. Därefter följer ett avsnitt om vetenskapsteoretiska principer som behandlar frågor om syfte, frågeställningar och anspråk, studiedesign, forskarrollen och kvalitetskriterier samt ett resonemang kring induktiva respektive deduktiva ansatser. Avslutningsvis redogörs för frågor kopplade till forskningsmetoder, som utgör ramverkets tredje domän. Här gäller det metoder för materialinsamling, analys, tolkning och rapportering. Texten spänner 